\title{
QUEEN'S
UNIVERSITY
BELFAST
}

\section{Experiences of youth justice: Youth justice discourses and their multiple effects}

McAlister, S., \& Carr, N. (2014). Experiences of youth justice: Youth justice discourses and their multiple effects. Youth Justice: An International Journal, 14(3), 241-254. https://doi.org/10.1177/1473225414549694

\section{Published in:}

Youth Justice: An International Journal

\section{Document Version:}

Peer reviewed version

Queen's University Belfast - Research Portal:

Link to publication record in Queen's University Belfast Research Portal

\section{Publisher rights}

(C) 2014 The Author

\section{General rights}

Copyright for the publications made accessible via the Queen's University Belfast Research Portal is retained by the author(s) and / or other copyright owners and it is a condition of accessing these publications that users recognise and abide by the legal requirements associated with these rights.

Take down policy

The Research Portal is Queen's institutional repository that provides access to Queen's research output. Every effort has been made to ensure that content in the Research Portal does not infringe any person's rights, or applicable UK laws. If you discover content in the Research Portal that you believe breaches copyright or violates any law, please contact openaccess@qub.ac.uk. 


\title{
Experiences of youth justice: Youth justice discourses and their multiple effects
}

\author{
Siobhán McAlister
}

(School of Sociology, Social Policy and Social Work), Queen's University Belfast, UK Nicola Carr

(School of Sociology, Social Policy and Social Work), Queen's University Belfast, UK

Corresponding author: Siobhán McAlister, School of Sociology, Social Policy and Social Work, Queen's University Belfast, Belfast, UK, BT71LP

Email: s.mcalister@qub.ac.uk

\begin{abstract}
Interventions within youth justice systems draw on a range of rationales and philosophies. Traditionally demarcated by a welfare/justice binary, the complex array of contemporary rationales meld different philosophies and practices, suggesting a mutability that gives this sphere a continued (re)productive and felt effect. While it may be increasingly difficult to ascertain which of these discourses is dominant in different jurisdictions in the UK, particular models of justice are perceived to be more prominent (Muncie, 2006). Traditionally it is assumed that Northern Ireland prioritises restoration, Wales prioritises rights, England priorities risk and Scotland welfare (McVie, 2011; Muncie, 2008, 2011). However, how these discourses are enacted in practice, how multiple and competing rationales circulate within them and most fundamentally how they are experienced by young people is less clear. This paper, based on research with young people who have experienced the full range of interventions in the youth justice system in Northern Ireland examines their narratives of 'justice'. It considers how different discourses might influence the same intervention and how the deployment of multiple rationalities gives the experience of 'justice' its effect.
\end{abstract}

\section{Key words}

Restorative justice, custody, youth justice discourse, experiencing justice 


\section{Introduction}

Across the UK the expansion of criminal and quasi-criminal interventions and modes of governance, alongside varied disposals and sanctions, has resulted in youth justice systems that enact multiple, contradictory and competing discourses (Fergusson, 2007; Muncie, 2004, 2006; Muncie and Goldson, 2006). While these are differentiated across time and place, the youth justice systems in separate jurisdictions within the UK tend to be associated with particular models of justice (e.g. welfare, rights, risk, restoration), and aspects of multiple discourses are evident in all. Research also demonstrates disjuncture between discourse, practice and experience whereby welfare-based models can be experienced coercively and punitively (McAra, 2006; Piacentini and Walters, 2006), and children's rights can be used to justify intrusive interventions (Muncie, 2006).

Further, the very nature of the discourses of welfare, rights, risk, responsibilisation, contain inherent tensions - care and control, child protection and public protection, child rights and victim rights. Thus, even where a particular model of youth justice is prominent, the meaning and experience is dependent on how interventions are institutionalised and enacted. Responses may be at the same time diversionary yet highly restrictive, welfare orientated yet punitive, rights focused yet exclusionary.

Based on the narratives of young people who have encountered numerous criminal justice interventions, and set within the context of the Northern Irish system which prioritises restorative practices and a human rights policy discourse, this paper examines how the competing ideologies and aims of the system are experienced. Taking the forms of 'justice' most often administered to young people in an ongoing study, we consider their experiences of youth conferencing and custody. Youth Conferencing, based on the principles of restorative justice, encapsulates some of the multiple and competing discourses of youth justice - responsibilisation, punishment, reintegration, risk, (victim's) rights. Custody is most often associated with the philosophical principles of punishment and public protection through incapacitation. Yet safeguards exist to limit its use with children and to protect those subjected to it. How these multiple and at times competing philosophies play out in the experiences of such interventions is examined. 


\section{Youth justice discourses}

Responses to young people in conflict with the law have usually taken account of their differential status to adults. Traditional justifications for intervention - welfare and justice - although less explicit today, continue to influence policy (Fergusson, 2007). As such, tensions and contradictions between care and control, welfare and justice exist alongside other articulations - rights and responsibilisation, punitiveness and informalisation - and are reflected to varying degrees (and sometimes simultaneously), in UK youth justice systems.

Welfare-orientated policies and practices are premised on the special status of children, particularly regarding 'responsibility'. Involvement in crime is linked with 'social problems', symbolic of deeper social and psychological difficulties rather than free rational and informed choice (Muncie, 2004). Interventions, therefore, prioritise the welfare needs of individual children which are better responded to outside the criminal justice system. Key is the aim to be child-centred, needs-focused and diversionary/ non-criminalising. These features appear to have much in common with more recent rights-based discourses of youth justice. Elements of this welfare model are also evident in current policies around diversion, prevention/ early intervention and multi-agency responses.

However, welfare-based initiatives can also serve disciplinary and regulatory functions, resulting in net-widening and disproportionate interventions (Brown, 2005; Cohen, 1985; Muncie, 2004). Demonstrating the disjuncture between justice as discourse and justice as practiced and experienced, the welfare-orientated model can involve high levels of coercion and punitiveness with legal rights eroded and children silenced (Muncie, 2004; Piacentini and Walters, 2006). Welfare can, therefore, be about control as much as care, it can be punitive as well as protective.

Concerns regarding lack of due process, proportionality and implementation of the rule of law, saw justice-based approaches foregrounded in recent years. With proponents arguing that a renewed focus on the offence ('deeds'), rather than the 'offender' ('needs') would result in more proportionate responses (Muncie, 2004). 
Young people in conflict with the law, while recognised as different to adults, are still rational actors, and thus responsible for their actions. Such rationalities marked the beginnings of what has been termed a 'punitive turn' in youth justice (Muncie, 2008) evidenced by 'a general diminution of welfare-based modes of governance in favour of various "justice" based responsibilisation and managerial strategies' (Muncie, 2005: 38).

Taking the changes of the past few decades together (e.g. adulteration, penal expansionism, risk factor prevention and responsibilisation), Muncie (2008) argues that modes of youth governance are more punitive, repressive and expansive today. They are focused on punishment and individual responsibility rather than welfare, child protection and support. While rates of custody have traditionally be taken as an indication of a punitive and authoritarian approach, Cohen's (1985) seminal work on the 'dispersal of discipline' is a reminder that a decline in imprisonment is not equated with less punishment and control. Further, in considering the fall in rates of youth custody in England and Wales, Bateman (2012) argues with reference to recent policy discourse, that this alone may not signal a shift in punitiveness.

Risk, responsibilisation and rights: Multiple and contradictory discourses

Contemporary youth justice involves multiple modes and layers of governance (Muncie, 2006). Recent initiatives focused on the prevention of offending through risk management illustrate the multiple and contradictory rationales within youth justice policy. Risk identification and management are premised on the basis of managing risk through intervening early in the lives of those displaying risk factors (Case, 2006). While early intervention programmes are presented as a benefit to the child and society, their welfare and rights-based ethos has been questioned (see Haydon this issue).

In line with neo-liberal governance and the risk management agenda, a key element of contemporary youth justice is responsibilisation (Phoenix and Kelly 2013). Here the young offender is considered a 'rational, responsible decision maker ...' (Gray, 2005: 938). The philosophical principles of restorative justice have married well with the responsibilisation agenda (Gray, 2005), because restorative justice emphasises 
an acknowledgement by the young person of the harm done. The focus on restoration and reintegration, however, also reflects the welfare discourse. Thus restorative justice can embody some of the tensions between welfare and justice holding young people to account but with a view towards them reintegrating into lawabiding society.

Research into young people's experiences of restorative justice has highlighted some of these tensions (Crawford and Newburn, 2003; Newbury, 2008). The range of interventions that often constitute restorative practices are individually focused, concentrating on the attitudes and behaviours of young people rather than the structural conditions of their lives (Gray, 2005). Newbury's (2008) analysis challenges the reintegrative functions of restorative justice, noting that behaviour is unlikely to change if young people feel they must accept responsibility despite mitigating factors and broader explanations.

Further demonstrating the tension between welfare and justice, restorative justice is embedded in the language of inclusion, participation and rights. Particularly suited to young people due to its 'informal' and sometimes diversionary nature, it incorporates the rights and views of victims and young people (e.g. Articles 12 and 40 of the UNCRC). Yet restorative justice can be experienced as punitive, exclusionary and shaming (Daly, 2002; Eliaerts and Dumortier, 2002). Concerns have also been raised regarding procedural safeguards in a forum where legal representation is absent (Eliaerts and Dumortier, 2002). While some research demonstrates relatively high levels of 'engagement' and participation by young people (e.g. Crawford and Newburn, 2003), this engagement and the levels of understanding of some has been questioned (Newbury, 2008). Whether young people feel they have a choice but to engage in the process, to accept responsibility and the resulting outcome is also debated (Hudson, 2003; O’Mahony and Campbell, 2006).

In sum multiple, competing and contradictory discourses are reflected to different degrees in youth justice systems and interventions. While this is acknowledged, how these discourses play out and more fundamentally how they are experienced by young people is less clear. This paper, based on research with young people who have encountered a broad range of youth justice interventions examines their 
experiences of 'justice'. Through their narratives we consider how different discourses might influence the same intervention and how the deployment of multiple rationalities gives the experiences of 'justice' its effect.

\section{Youth justice in Northern Ireland: Prioritising restoration}

Elements of broader trends in youth justice including an increased focus on risk and the centrality of the victim are evident in Northern Ireland's youth justice system (see Muncie, 2008, 2011; Muncie and Goldson, 2006). However, political conflict and subsequent conflict transformation have shaped the contours and structures of youth justice practice. This is most evident in the emergence of restorative justice as the main disposal.

A core component of the peace process (1998) was a commitment to review policing and criminal justice and to embed accountability, human rights and transparency into institutions and their practices. Following from the Criminal Justice Review (2000), the Justice (NI) Act (2002) established a central agency with responsibility for youth justice and set out the aims of the new youth justice system. Here the principle aim is the protection of the public through preventing offending by children. Emphasising the centrality of responsibilisation, young people are to be encouraged 'to recognise the effects of crime and to take responsibility for their actions'. These aims are to be implemented with consideration for the welfare of the child. The ordering of these principles, in particular the relegation of welfare has been the subject of some critique (Youth Justice Review Team, 2011). Further, these aims demonstrate the multiple discourses underpinning the system. The discourses of risk, responsibilisation and public protection sit alongside those of welfare, rehabilitation and rights.

The Justice (Northern Ireland) Act (2002) introduced new diversionary disposals, community and custodial orders and formalised restorative justice through the Youth Conference Service. Adapting methods of conflict resolution restorative justice is reflective of the wider aims of transitional justice intended to close the legitimacy gap in state administered criminal justice (Doak and O'Mahony, 2011). The legislation provides that where a young person admits guilt the Public Prosecution Service 
(PPS) or the Court must direct that a Youth Justice Conference is held unless the offence falls under a small number of excluded serious offencesi. The output of the youth conference, the Conference Plan, is approved by either of the directing parties (PPS or Court). Conference Plans typically contain requirements for the young person to write a letter of apology to a victim, and to engage in forms of reparative work and other purposeful activities.

Over time the numbers of youth conferences has risen markedly. A total of 1,556 referrals for a conference were made to the Youth Justice Agency in 2012-2013 compared to 172 referrals in 2005 (DeCodts and O'Neill, 2014). As youth conferencing has expanded and become the primary youth justice response, the numbers of young people in custody has declined. The transformation of Northern Ireland's youth justice system and in particular the emphasis on restoration has been hailed internationally as a success story (Doak and O'Mahony, 2011; Jacobson and Gibbs, 2009). However, this transformation is not uncontested (Convery, 2013; Convery et al., 2008). In respect of restorative justice, the efficacy and proportionality of multiple conferencing has been questioned (CJINI, 2008; Youth Justice Review Team, 2011). Criticisms similar to those previously described have emerged in local research. Specifically: problems with the focus on individual responsibility; feelings of a lack of inclusion and 'equal' input from young people; oppressive and punitive proceedings and disproportionate outcomes (see Maruna et al., 2007; O'Mahony and Campbell, 2006).

Overall, however, the experiential aspects of youth justice have been given less coverage in broader narratives about system transformation. A decline in the use of custody and the prominence of restoration do not necessarily account for how justice is perceived in practice - whether for example restoration is found to be responsibilising or reintegrative. Given the multiplicity of rationales and the range of young people to whom they are applied inevitably there will be differing accounts of these experiences. In the next section we explore how such rationales are played out for young people.

\section{Methodology and background to the study}


The data presented in this article is based on interviews with young people who were remanded or serving a sentence in Woodlands Juvenile Justice Centre (JJC). Woodlands is a purpose-built facility managed and staffed by the Youth Justice Agency (YJA). The centre accommodates almost all young people under 18 detained within the criminal justice system ${ }^{i i}$. Young people can also be detained here under Police and Criminal Evidence (PACE) provisions, following arrest and charge and pending their court appearance. The ongoing study, funded by the YJA, focuses on the transitions of young people into and out of custody. Research participants were selected on a purposive basis taking account of the heterogeneity of the population including gender, routes of admission, offences and home areaiii.

The sample includes 21 young people, two young women and 19 young men, aged between 15 and 17 at the time of the first interview. The first interview normally takes place in the JJC prior to the young person's release. It comprises of a life-history interview (Atkinson, 1998; Coles and Knowles, 2001), where young people are invited to 'tell the story of their life' including the reasons why they are detained at this time. In addition to exploring the young person's previous contacts with the criminal justice system, the interview explores their hopes and plans for the future, particularly the plans in place for their release from custody. Follow-up interviews take place following young people's release from custody; here the focus is on their transition from custody, what has been happening in their lives and any challenges that have arisen. The data presented in this article focuses specifically on young people's experiences of justice. Here we focus on two aspects of the youth justice system - restorative justice (youth conferencing) and custody.

\section{Young people's experiences of justice}

Most of the young people had multiple interactions with the youth justice system over a sustained period of time. A number had contact with the criminal justice system prior to reaching the age of criminal responsibility (age 10) through family involvement and contacts with the police. Experiences with the police were often fraught. There were numerous accounts of feeling over-policed (particularly in discussing the policing of bail conditions), and expressions of discrimination and targeting. In addition to formal policing, around half of the sample $(n=11)$ had also 
experienced 'policing' by paramilitaries. This included intimidation, threats and warnings, physical beatings and exilings. This informal punishment, regulation and control when added to experiences with the formal criminal justice system, amounted to multiple forms of punishment.

While for a small number of young people contact with the criminal justice system was minimal, more usual was a long history of involvement with young people having experienced a number of previous interventions, including remands into custody, extensive bail conditions, youth justice conferences and community-based sanctions. Under legislation there is no limit to the number of youth conferences that a young person can be made subject to and many of the young people that we interviewed had taken part in multiple conferences.

Restorative justice

Based on restorative justice principles, the purpose of the youth conference as outlined in guidance for young people is to ${ }^{\mathrm{iv}}$ :

... give you a chance to tell the people at the meeting why you committed the offence. It gives the victim a chance to tell you how they have been affected by what you did to him or her. ... The meeting will want you to: .... Agree an action plan to make up for what you have done and stop offending.

Young people reported variable experiences of this process. For some, conferencing, or at least what they were required to do for their conference plan, provided some structure in their lives. Kyle, who was on remand for a serious violent offence and who had multiple previous offences, explained how the activities required under his conference plans provided him with something to fill his time:

I: $\quad$...did you ever find the conferences useful or helpful?

R: No, it just got me off the streets really. So they gave me something stable so they did, 'cos I was going in and out of there (YJA) 4 or 5 days a week like so I was. And if I hadn't been doing it, I would have been just lying awake getting stoned like. Kyle (age 16) 
It is noteworthy that it was not the content of the programmes that Kyle identified as useful, or the conference itself, rather that the Plan provided him with purposeful activity.

At the time of his initial interview, Kevin was serving his first custodial sentence for involvement in riotous behaviour. He had previous convictions for similar offences and had been through the youth conference process. His account of some of the requirements of his conference plan provides an example of having to confront the impacts of his offending. On this occasion Kevin describes visiting a residence to hear about the impact of rioting on those living there:

... because I was rioting outside an 'aul (old) people's home, I went up... and I writ them a letter saying I was sorry, and then I went up telling them I was all sorry. And then they took me on a wee tour around the place...I felt alright saying sorry, but I felt like an asshole for rioting outside their place, so I did...It made me feel a bit lousy on them and all because of how close it was...I went and met the manager, 'cos they were saying - 'how do you feel'?, and all And I said - 'I feel like a ... dickhead' and all that there. And I went around and said sorry and I was shaking people's hands saying I was sorry for rioting outside and I writ them a letter...

This experience had a clear impact on Kevin. As he described it, meeting the residents of the home made him feel a sense of shame. The shaming element of restorative justice draws on the theory of 'reintegrative shaming' (Braithwaite, 1989), which contends that social disapproval impacts on how a person feels about their offence, ideally dissuading them from such behaviour in the future. A component of this approach, and an underlying premise of restorative justice, is that a reintegration or restoration takes place for the victim of the offence and for the offender (Harris, 2006). Thus, a distinction is drawn between reintegrative shaming - i.e. shaming that is respectful of the person, avoids labelling and ends with forgiveness - and stigmatizing shaming (Ahmed and Braithwaite, 2005). 
While Kevin spoke about the salutary effect of this particular conference, he had subsequently been convicted of further rioting offences resulting in his current sentence. Sometimes explaining his behaviour in individual terns (defining himself as a 'hood'v), Kevin also described his feelings of boredom, the lack of things to do in his community and by contrast the excitement of rioting: 'you get like an adrenaline rush so you do...it's good.' Within the local context rioting has historically been a masculine form of cultural expression and resistance (Haydon et al, 2012). It can be seen, therefore, that despite restorative interventions the context and circumstances of Kevin's life, continued to impact heavily on his offending behaviour.

For some young people, their experiences of conferences were more stigmatizing than reintegrative. Aged 15, and serving a sentence for a violent offence Paul had experience of multiple conferences. He recounted his first conference where the victim was antagonistic towards him:

I had to show remorse for what I'd done like...like for the different offences, like I was in a youth conference there ages ago for a burglary, it was one of my first offences, and I just got diverted to a youth conference because it wasn't a serious burglary, you know. I had to sit in a room with the person from the shop and I had to sit there and just to listen to him and say sorry and all. He just sat there and gave me abuse basically, he was an English boy and he called me a 'yob' or something like that. I hadn't a clue what that meant, I had to say - 'what the fuck's a yob like?' And he says a 'hood' or something like that it is. And I said - 'I'm no hood'.

Over time and following participation in further conferences, Paul describes 'wising up' and learning what is expected of him:

You know, that was me back in that time, and then going through youth justice and all, I started wising up a bit, started getting street smart you know instead of being stupid. Just all I had to do, all of the youth conferences, then after that I would have just sat there and said 'sorry'. You know, just listening to them go on and on, (I) wouldn't give a fuck. I would have sat there and said 'sorry' instead of arguing with them, you know what I mean? Paul (age 15) 
Clearly Paul had learnt to adapt his initial strategy of resistance, challenging and talking back, to one where he says the 'sorry' that is required of him. The inclusive and participatory nature of conferences was greatly questionable in Paul's experience. Garrett (age 17) described a similar feeling of saying what is required:

...you just have to sit down, and basically pretend, or not pretend, say you're sorry and look like you're sorry and that's it...

Part of the difficulty here arises from the over-simplified binary categorisations of 'victim' and 'offender', and for some the sense of injustice this arouses. Taking the moment, the interaction of the offence as the instance in which the young person (the 'offender') is held to account, and in which s/he must demonstrate remorse and accountability before the legitimate 'victim', belies the realities of many of the young people's lives beyond these moments. For, Hugh (age 16), his life had been characterised by multiple losses and he described intense feelings of despair. Youth conferences where he had to account for behaviour that he could not fully recall because of alcohol use were particularly difficult:

...just like sitting there and listening, listening to like listening to everything that I did and 'cos it was all alcohol and it was all I felt so shit about it like, so bad. And see like a few months down the line at that conference listening to it again like just... you know when the alcohol was on board I didn't care and then a few months down the line I had the conference just hearing it all again it was just killer like.

Strategies of responsibilisation 'holding young people to account' are evident from the official youth justice discourse and in young people's own recounting of their experiences. Internalising the message of the need to take responsibility and selfmanage Hugh feels the responsibility to change, particularly in light of a further admission to custody, as resting firmly on his shoulders. Despite recognising the harm done and feeling deep shame, Huge recognised this was not enough: 
l'd say if you asked ... the conference worker well I wouldn't really say it hit home much with where I am sitting (in custody) at the moment. It's up to me to change it like.

While Morris (2002) cautions against a false binary between restorative and retributive justice or indeed pinning unrealistic expectations on restorative processes, here the challenges of restoration are apparent. While the focus of any conference is on the harm caused, the meaningfulness of restoration and reintegration particularly into families and communities from which young people feel alienated is raised in many of the young people's accounts. Recognising the harms caused by offending was not something young people typically shied away from, however, they recounted the responsibility for restoration as resting primarily on them. The contents of Conference Plans, perhaps reflecting the offending history of some, were at times expansive and onerous. Some noted the 'stress' that managing multiple conditions could cause and a few noted not agreeing with the outcomes even though they had accepted them. While few discussed the programmes they had to undertake in any manner that would suggest a rehabilitative effect, their value for providing something to do in otherwise monotonous lives is noteworthy in its own right. It speaks to the lack of opportunities for young people living in communities often beleaguered by poverty, under-investment and the legacies of the Conflict.

\section{Experiences of custody}

Paradoxically, but perhaps unsurprisingly given their life experiences and ongoing issues within their communities, for many young people detention was described as a period of respite. Having their needs met and the relative 'ease' of the JJC in comparison to life outside was evident:

Life is so easy in here. You have no worries about people looking for you, no worries about nothing. You have no worries about going hungry and getting food and things like that.

Robbie (aged 16)

Reference was made to the range of activities available in the Centre and the fact that there was a structure and routine to daily life: 
It's a gift. I don't know, don't worry about nothing like. Whatever you need is there...the food's rotten though. There's all sorts of activities you can do in it like. They show you options and everything you can do when you get out and all.

Patrick (age 17)

Anthony (aged 17) had been in and out of the JJC since the age of 11. He estimated that he had spent two years in detention between various remands and sentences. Using drugs for many years - 'solvies and meth and coke, E's everythin' - for him the JJC offered an opportunity to detox:

I like it in here, it's good... Cos it's kinda a detox centre, you just come in and get off all the drugs and all and get fit again.

Anthony (age 17)

Raising questions about the availability of appropriate services for young people in the community, like Anthony, Hugh had also experienced multiple admissions and the JJC was a place where he came off drugs. While ultimately he saw this as positive, this process was not without its pains:

It makes me feel, it's like I try, and this place is sort of like a place where people come off things. This is hard, you have to come off things in here ... it is not like you can turn round and say 'give me something, give me cannabis, give me a smoke'. You can't, you have to do it you have to come off them. And it is hard like... I have got these shakes sometimes I feel real not meself and but that's why I do alternatives like go to the gym, do weights just take me mind of things really. Better than sitting smoking me brains out you know.

Hugh (age 16)

The experience of many young people was that the JJC met their welfare needs, underlining the fact that these were not being met elsewhere. In a number of interviews young people also noted the materiality of their surroundings in detention. Some who had come here for the first time reported that it did not meet their expectations of what a prison or place of detention would be - they had their own rooms and access to resources that were not necessarily available to them on the 
outside. This is not to suggest that young people did not want their freedom, and that there were not pains associated with confinement, but in many accounts the positive welfarist aspects of having their basic needs met, whilst at the same time desiring to be on the outside were noted.

For some, like Hugh the desire to be free in the literal sense and also from drugs was double-edged, because he was not sure if he would have somewhere to go on release or if he could sustain abstinence on the outside. The anticipation of rejection by his family who did not want him to return home permeated his account and while he desired to be free, the thought of what would happen to him on release was a source of anxiety:

I don't have a problem with bein' in here (custody) 'cos, I don't know, I guess you just get used to it after a few times. But then it's just the fact that when you have bail you just have nowhere to live, it's the worst thing that could possibly happen to ya.

Hugh (age 16)

Contact with families and friends on the outside was both a source of comfort and anxiety for many young people. Some young people worried about their families making the journey to visit them, they described looking forward to a visit but feeling down afterwards as this accentuated their experience of being confined and away from home. Because the $\mathrm{JJC}$ is the only place for detained young people in Northern Ireland many families have to make long journeys to get there. While the JJC has an accommodation unit where families and visitors can stay overnight, young people were often conscious about the burden that their detention placed on their families. For Stevie, the impact of his mother visiting was known as he witnessed it first hand when his older brother was in prison:

... when (brother was in prison) me ma went up and down but she used to be stressed, she says 'this is costing me a fortune'. Diesel and then needin' fifty pound a time for buyin' clothes and all that. I knew it was a nightmare like, that's why I said 'I'll see you once I get out', but she came up the last time and left me money and all... 
For young people then, experiences of custody were both punitive in terms of the deprivation of liberty and all that entailed, but also welfarist in that they perceived their needs were being met where they were not elsewhere.

\section{Discussion and conclusion}

Young people's accounts of their experiences of these two justice interventions youth conferencing and custody - provide an illustration of the range of rationalities at play within the youth justice system. The mix of responsibilisation, restoration, welfarism and punitiveness is evident. The impulse towards responsibilisation of 'holding young people to account' for the harms they have caused is clear in some of the experiences of restorative justice, where young people are required to hear the views of the victims of their offences and to make amends. Depending on the particular circumstances and dynamics of the process, these encounters can be experienced as shameful or punitive. They can also become devoid of meaning, a performance of reform where young people understand the rules and what is required of them - they 'wise up' and they give the requisite apology. In other instances experiences of shaming are characterised more re-integratively. A clear pre-requisite here is that the young person feels that they are treated with respect and that they are not stigmatised within this process.

The aim of restoration as young people experience it, largely places the burden of restoration and reform on their shoulders. The question of their wider experiences, including multiple traumatic life events, poverty, paramilitary punishments and other forms of exclusions are for many not addressed in a meaningful way. This is not to say that attempts are not made to do this, young people are provided with the opportunity to give their account, but for many this accounting in this setting is too difficult and to what effect? While the formulations of conference plans variously include letters of apology, engagement in voluntary work, attendance at anger management and drug and alcohol programmes and so forth, these too are largely premised on indivualised reform and responsibility.

That incarnations of restorative justice do not achieve the desired effects for these and other young people is not a reason to rubbish its intentions (Morris, 2002). The 
point is to illuminate the fact that discourses are given multiple effects in practice. Here restoration as perceived is about responsibiisation and for some it is punitive. Similarly the data on young people's experiences of custody, an intervention most associated with punitiveness, points to contradictory strains and 'oscillating rationales' (Muncie, 2006: 771) in the youth justice sphere. The accounts of young people highlight that for some detention was the means to meet their welfare needs and this was preferable to them than circumstances where their freedom in the community was restrictively curtailed, for example through the imposition of multiple bail conditions. Thus, a contingent community existence was viewed more punitively than custody.

The argument is not of course that custody should not espouse welfarist rationales, but rather that this was the place where welfare needs (substance misuse and mental health difficulties, homelessness, etc.) had to be met. This is the larger indictment. While the numbers of young people in custody over time has declined, the impulse for its use, grounded in such rationales - preventative, public protection and welfarist - remains. It is the multiplicity and adaptability of these various rationales that continue to give custody and other youth justice interventions their (re)productive and felt effect.

\section{References}

Ahmed E and Braithwaite J (2005) Forgiveness, shaming, shame and bullying. Australian and New Zealand Journal of Criminology 38(3): 298-323.

Atkinson R (1998) The Life Story Interview. London: Sage.

Bateman T (2012) Who pulled the plug? Towards an explanation for the fall in child imprisonment in England and Wales. Youth Justice 12(1): 36-52.

Braithwaite J (1989) Crime, shame and reintegration. Cambridge, UK: Cambridge University Press. 
Brown S (2005) Understanding Youth and Crime: Listening to Youth? Berkshire: Open University Press.

Case S (2006) Young People "At Risk" of What? Challenging Risk-focused Early Intervention as Crime Prevention. Youth Justice 6(3): 171-179

Cohen S (1985) Visions of Social Control. Cambridge: Polity Press.

Cole AL and Knowles GJ (2001) Lives in context: The Art of Life History Research. Lanham: AltaMira Press.

Convery U, Haydon D, Moore L and Scraton P (2008) Children, Rights and Justice in Northern Ireland: Community and Custody. Youth Justice 8(3): 245-263.

Convery U (2013) Locked in the past: An historical analysis of the legal framework of custody for children in Northern Ireland. European Journal of Criminology 11(2): 251269.

Crawford A and Newburn T (2003) Recent Developments in Restorative Justice for Young People in England and Wales: Community Participation and Representation. British Journal of Criminology 42(3): 476-495.

Daly K (2002) Restorative Justice the real story. Punishment and Society 4(1): 5579.

DeCodts M and O'Neill N (2014) Youth Justice Agency Annual Workload Statistics 2012/13 Statistical Bulletin 1/2014. Belfast: DoJ (Department of Justice).

Doak J and O'Mahony D (2012) In search of legitimacy: restorative youth conferencing in Northern Ireland. Legal Studies 31(2): 305-325.

Eliaerts C and Dumortier E (2002) 'Restorative justice for children: in need of procedural safeguards and standards.' In: Weitekamp EGM and Kerner HJ (eds.) Restorative Justice Theoretical Foundations. Cullompton: Willan, pp. 204-223. 
Fergusson R (2007) Making sense of the melting pot: Multiple discourses in Youth Justice Policy. Youth Justice 7(3): 179-194.

Gray P (2005) The politics of risk and young offenders' experiences of social exclusion and restorative justice. British Journal of Criminology 45(6): 938-957.

Haydon, D., McAlister, S., Scraton, P. (2012) 'Young People, Conflict and Regulation.' Howard Journal of Criminal Justice, 51,5: 503-520

Harris N (2006) Reintegrative Shaming, Shame, and Criminal Justice. Journal of Social Issues 62(2): 327-346.

Hudson B (2003) Understanding Justice: An Introduction to Ideas, Perspectives and Controversies in Modern Penal Theory. Buckingham: Open University Press.

Jacobson J and Gibbs P (2009) Making Amends: Restorative Justice in Northern Ireland. London: Prison Reform Trust.

McAra L (2006) Welfare in crisis? Key developments in Scottish Youth Justice. In: Muncie J and Goldson B (eds.) Comparative Youth Justice. London: Sage, pp. 127145.

McVie S (2011) Alterative models of youth justice: lessons from Scotland and Northern Ireland. Journal of Children's Services 6(2): 106-114.

Maruna S, Wright S, Brown J, Van Marle F, Devlin R and Liddle M (2007) Youth Conferencing as Shame Management: Results of a Long-Term Follow-up Study. ARCS UK: Available at: http://youthjusticeagencyni.gov.uk/document_uploads/SHAD_MARUNA_STUDY.pdf Morris A (2002) Critiquing the critics: A brief response to critics of restorative justice. British Journal of Criminology 42(3): 596-615 
Muncie J (2004) Youth and Crime, London: Sage.

Muncie J (2005) The globalization of crime control - the case of youth and juvenile justice: Neo-liberalism, policy convergences and international conventions. Theoretical Criminology 9(1): 35-64.

Muncie J (2006) Governing young people: Coherence and contradiction in contemporary youth justice. Critical Social Policy 26(4): 770-793.

Muncie J (2008) The 'punitive turn' in juvenile justice: Cultures of control and rights compliance in Western Europe and the USA. Youth Justice 8(2): 107-121.

Muncie J (2011) Illusions of difference: Comparative youth justice in the devolved United Kingdom. British Journal of Criminology 51(1): 40-27.

Muncie J and Goldson B (2006) States of transition: Convergence and diversity in international youth justice. In: Muncie J and Goldson B (eds.) Comparative Youth Justice. London: Sage, pp. 196-218.

Newbury A (2008) Youth crime: Whose responsibility? Journal of Law and Society 35(1): 131-149.

O'Mahony D and Campbell C (2006) Mainstreaming Restorative Justice for Young Offenders through Youth Conferencing: The Experience of Northern Ireland. In: Junger-Tas J and Decker SH (eds.) International Handbook of Juvenile Justice, pp. 93-115.

Phoenix J and Kelly L (2013) "You have to do it yourself": Responsibilzation in youth justice and young people's situated knowledge of youth justice practice. British Journal of Criminology 53(3): 419-437.

Youth Justice Review Team (2011) A Review of the Youth Justice System in Northern Ireland. Belfast: DoJ 
Author biographies: Siobhán McAlister and Nicola Carr are lecturers in Criminology in Queen's University Belfast

'The following offences are precluded from being dealt with by way of a youth justice conference under the
Justice Act, 2002 [33A, 2](a) offences the sentence for which is, in the case of an adult, fixed by law as
imprisonment for life; (b) offences which are, in the case of an adult, triable only on indictment; and(c)
offences which are scheduled offences for the purposes of Part 7 of the Terrorism Act 2000 (c. 11).
ii In line with recommendations for The Youth Justice Review (2011), in late 2012 the Department of Justice
announced the end of detention of under 18's within the prison system, except in specific cases (e.g. where
there were serious security risks such as the involvement of a young person in dissident activity).
iii Young people who are currently looked after are not included in the sample as this requires a separate
research governance and ethical approval process.
iv Youth Justice Agency leaflet for young people: Youth Conference: Your Decision. Available at:
http://www.youthjusticeagencyni.gov.uk/document uploads//Youth conference Your Decision.pdf
${ }^{v}$ 'Hood' is a localism for those who take part in criminal activities, particularly rioting with the police, for 'fun'. 